\title{
Loess Dating Progress in China
}

Loess is a sediment difficult to date. The loess sequences of the last climatic cycle in China are usually dated by radiocarbon and thermoluminescence (TL) measurements. Correlation with marine $\delta^{18} \mathrm{O}$ records and orbital cycles is also frequently used for the construction of time-scales. In previous studies, soil S0 was correlated with the deep-sea oxygen isotope stage 1; loess L1 was correlated with isotope stages 2,3 and 4 , the weak soil complex within L1 with stage 3 , and the $S 1$ soil with stage 5 .

Recently, the Weinan loess section was intensively dated for determining the ages of the major stratigraphic boundaries using TL and twenty-eight radiocarbon dates. The radiocarbon dating was carried out on the humin fraction of the organic matter in the samples using AMS. The results confirms the previous land-

sea correlation pattern except for the lower boundary of the soil complex in the Malan loess (Fig. 1): most of the TL dating yielded ages centered at $\sim 50 \mathrm{ka}$, which is significantly younger than the age of stage 3 ( $\sim 59 \mathrm{ka})$ according to Martinson et al (1987). The TL age is, however, in good agreement with the oxygen isotope age of $\sim 50$ ka provided by the eolian dust record in the North Pacific (Hovan et al. 1989), which represents a direct link between the Chinese loess and marine $\delta^{18} \mathrm{O}$ records. These dates provide an independent timescale for the loess-paleosol sequence of the last climatic cycle.

\section{JiAQI LIU AND Tungsheng LIU}

Institute of Geology, Chinese Academy of Sciences, P.O. Box 9825, Beijing 100029, China

Tiemel Chen

Dept. of Archeology, Beiijing University, China
Fig. 1: Depth-Age transformation of the Weinan loess section based on absolute dating compared with that obtained by correlating with the SPECMAP time scale (figure from Liu J.Q. et al., 1994).

SPECMAP data are from Imbrie et al., 1984). 1. AMS 14C age; 2. TL age; 3. stratigraphic boundary age obtained through correlation with SPECMAP $\delta^{18} \mathrm{O}$ record; 4. Loess; 5. Paleosol
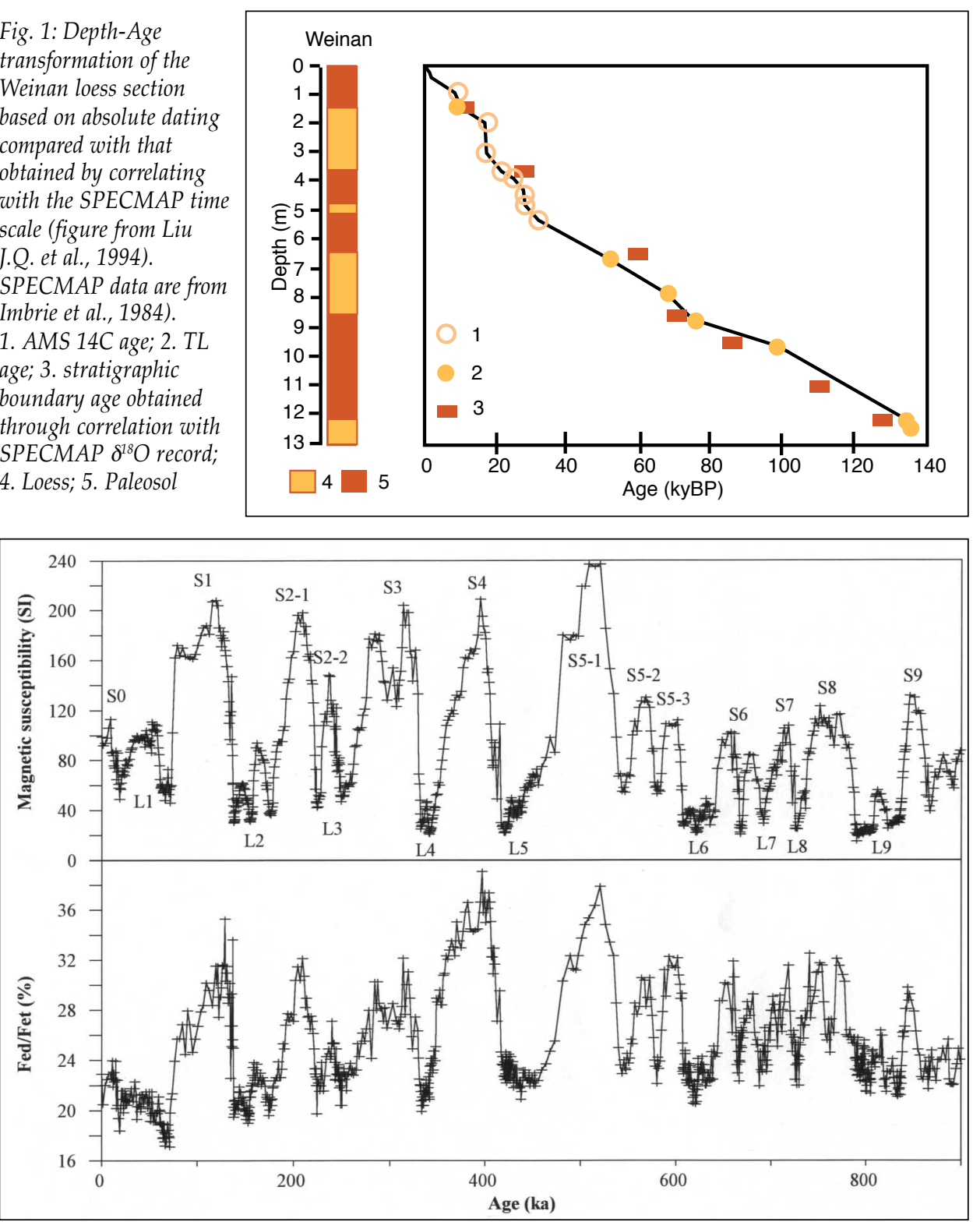

Fig. 2: Variations in the Fed/Fet ratio from the Changwu loess section compared with the magnetic susceptibility values. The timesacle is obtained by correlating the susceptibility signals with that of Xifeng (see Kukla et al., 1990, Trans. Royal Society of Edinburgh: Earth Sciences, 81:263-288)

\section{A new Proxy of the East Asian Paleomonsoon}

Magnetic susceptibility variations in Chinese loess-paleosol sequences are used by many authors as a proxy for the strength of East-Asian summer monsoon. Susceptibility values are higher in paleosols than in the overlying and underlying loess. Recently, we carried out a paleopedological study on three loess sections (Weinan, $34.33^{\circ} \mathrm{N}, 109.5^{\circ} \mathrm{E}$; Changwu $35.2^{\circ} \mathrm{N}, 107.8^{\circ} \mathrm{E}$ and Xifeng $35.7^{\circ} \mathrm{N}$, $107.6^{\circ} \mathrm{E}$ ) for the last $900 \mathrm{ka}$ using various pedological methods and found that the susceptibility value is not always consistent with the pedological indicators (Fig. 2). For example: (1) The S4, S5-1 and S5-3 soils represent the most developed soils while the susceptibility values for S4 and S5-3 are not higher than for the other soil units (in the case of S5-3 they are even lower). (2) For the three sub-units of S5, the intensity of pedogenesis shows an order of S5-1 (strongest), S5-3 and S5-2 (weakest) while the susceptibility shows an order of S5-1 (highest), S5-2 and S5-3 (lowest). (3) The soils S6, S7 and $S 8$ are similar to $S 2$ and $S 3$ while the susceptibility values for the major soil units older than S5-1 are much lower than for the younger interglacial soils (S0 to S5-1), even lower than for some weakly developed interstadial soils in the loess units L1, L2 and L3. These results therefore provide a complex picture for the climatic significance of the magnetic susceptibility in paleosols. Understanding the basis of this complexity will require much additional work. The Loess Plateau is located in the EastAsian monsoon zone. Since the average soil temperatures in the region are below $0^{\circ} \mathrm{C}$ from late autumn to early spring under modern interglacial conditions, the chemical weathering of loess mainly depends upon summer temperatures and precipitation. Consequently, a chemical weathering index would be expected to reflect the paleomonsoon intensity: high weathering intensity can be interpreted as an indication of strengthened summer monsoon and lower weathering intensity indicates the reverse. Recently, we have generated a high-resolution paleo-weathering

The PAGES report 96-4 "Continental Drilling for Paleoclimatic Records" has been reprinted by the Geoforschungszentrum Potsdam and is again available in hardcopy from the PAGES IPO in Bern.

The report is also available in $\mathrm{html}$ form on the PAGES website http:/ $\angle$ www.pages.unibe.ch/. 